\title{
Vascular endothelial growth factor gene polymorphisms and renal cell carcinoma: A systematic review and meta-analysis
}

\author{
YONG ZHANG ${ }^{1,2}$, SHENG LI $^{3}$, HOU-QIN XIAO ${ }^{2}$, ZHAO-XIONG HU ${ }^{2}$, YAN-CHENG XU $^{1}$ and QI HUANG ${ }^{1}$ \\ ${ }^{1}$ Department of Endocrinology, Zhongnan Hospital, Wuhan University, Wuhan, Hubei 430071; \\ ${ }^{2}$ Department of Nephropathy, Taihe Hospital, Hubei University of Medicine, Shiyan, Hubei 442000; \\ ${ }^{3}$ Department of Urology, Zhongnan Hospital, Wuhan University, Wuhan, Hubei 430071, P.R. China
}

Received February 2, 2013; Accepted July 1, 2013

DOI: $10.3892 / \mathrm{ol} .2013 .1499$

\begin{abstract}
Renal cell carcinoma (RCC) accounts for 3\% of all cancer-related mortalities in adults. The risk factors for the development of RCC remain under investigation. Vascular endothelial growth factor (VEGF) is a key mediator of angiogenesis and is crucial for the development and metastasis of tumors, including RCC. VEGF gene polymorphisms may alter VEGF protein concentrations, affect the process of angiogenesis and may be involved in inter-individual variation in carcinogenesis. In the present study, a systematic review and meta-analysis were performed based on published case-control studies in order to estimate the association between VEGF gene polymorphisms and the susceptibility to RCC. A total of five studies that involved eight polymorphisms and were published between January 2000 and December 2012 were identified from PubMed. The results of this systematic review and meta-analysis indicate that the VEGF 936C/T, 1612G/A, -1154G/A, -2549I/D, -460T/C and $405 \mathrm{G} / \mathrm{C}$ gene polymorphisms are not associated with the risk of RCC. There was no polymorphism in $702 \mathrm{C} / \mathrm{T}$ and $\mathrm{RCC}$ and the $-2578 \mathrm{C} / \mathrm{A}$ gene polymorphism may be associated with an increased risk of RCC. However, due to the limitations of the present study, further high quality case-control studies are warranted to confirm these findings.
\end{abstract}

\section{Introduction}

Renal cell carcinoma ( $\mathrm{RCC})$ is the seventh most common cancer in males and the ninth most common cancer in females, and accounts for $2 \%$ of all malignant diseases in adults (1). RCC continues to be a devastating cancer and the worldwide incidence and mortality rates are rising at a rate of $2-3 \%$ per decade (2). Furthermore, the initial clinical course of RCC is asymptomatic, resulting in $25-30 \%$ of patients presenting with metastatic

Correspondence to: Professor Yan-Cheng Xu, Department of Endocrinology, Zhongnan Hospital of Wuhan University, Shuiguohu Road, Wuchang, Wuhan, Hubei 430071, P.R. China.

E-mail: xuwhuedu@163.com

Key words: vascular endothelial growth factor, polymorphism, renal cell carcinoma, risk, meta-analysis disease at the time of diagnosis (2). To date, the definite etiology of RCC remains unclear. A number of studies have shown that active and/or passive smoking (3), moderate and/or heavy alcohol consumption (4), obesity $(5,6)$ and hypertension (7) are established risk factors that play key roles in the development of RCC. However, as they do not entirely explain the etiology, there may be other risk factors that are involved. With developments in molecular biology, researchers have investigated whether genetic factors are involved in RCC development.

Vascular endothelial growth factor (VEGF) is a potent endothelial cell mitogen that plays a key role in angiogenesis $(8,9)$. Compelling evidence from meta-analyses has indicated that VEGF gene polymorphisms are associated with the risk of various diseases, including gastric cancer (10), pre-eclampsia (11), cardiovascular disease (12) and amyotrophic lateral sclerosis (13). The VEGF receptors, VEGFR1, VEGFR2 and VEGFR3, have significant roles in the signaling pathways that are involved in RCC pathogenesis, and mutations in VEGFRs may affect the signaling networks (14). Therefore, VEGF gene polymorphisms may be associated with RCC. In 2002, Abe et al (15) investigated the association between single nucleotide polymorphisms in the 3'-untranslated region (UTR) of the VEGF gene and RCC in the Japanese population, and indicated that the C702T, C936T and G1612A polymorphisms in the 3'-UTR of the VEGF gene are not associated with the risk of RCC. However, their results showed significant ethnic differences in the frequencies of the C702T and G1612A alleles (15).

Certain studies have also been performed to detect the association between VEGF gene polymorphisms and RCC, and the results are varied. The present systematic review and meta-analysis aims to present the genetic knowledge on the VEGF gene polymorphisms and RCC risk in humans based on the published evidence.

\section{Materials and methods}

Literature selection. The proposed Preferred Reporting Items for Systematic reviews and Meta-Analyses (PRISMA) (16) statement was followed to report the present meta-analysis. Initially, the published studies that tested the association between VEGF gene polymorphisms and RCC were identified by searching PubMed for studies that were published between 
January 2000 and December 2012. The search terms that were used were 'renal cell' and 'carcinoma' or 'cancer' and 'vascular endothelial growth factor' or 'VEGF' and 'polymorphism', 'mutation' or 'variation', without restrictions. In addition, the reference lists of retrieved papers and recent reviews were also examined.

Study selection. Any study that matched the following criteria was included: i) A case-control study design; ii) an association between VEGF gene polymorphisms and RCC in humans; iii) RCC confirmed by the accepted diagnostic criteria; iv) inclusion of the odds ratio (OR) and the corresponding $95 \%$ confidence intervals (CIs), or the number of events that may be used to calculate them.

To evaluate the eligibility of all the studies retrieved from the databases on the basis of the predetermined selection criteria, two independent investigators were used. Disagreements were resolved by discussion.

Data extraction. The two independent reviewers extracted the following data: gene polymorphisms, first author's last name, year of publication, site of origin, source of controls, matching criteria, number of cases and controls, number of different genotypes in cases and controls, Hardy-Weinberg equilibrium (HWE) and minor allele frequency in controls. Any disagreements were resolved by consensus.

Data analysis. The articles that met the inclusion criteria were identified and classified according to the gene polymorphisms that they described. Subsequent to categorizing the data, a descriptive analysis of the data that were unsuitable for conducting the meta-analysis was performed. The data that were suitable for pooling were used in the meta-analysis.

A pooled OR and 95\% CI was computed for the risk allele using RevMan 5.1 (Nordic Cochrane Centre, Copenhagen, Denmark) to generate forest plots, in order to determine whether a statistical association was present between the case and control groups and to assess the heterogeneity of the included studies. The HWE was tested by a $\chi^{2}$ test at a significance level of $\mathrm{P}<0.05$. Heterogeneity was quantifiably evaluated using the $\chi^{2}$-based Cochran's Q statistic (17) and the $\mathrm{I}^{2}$ statistic (18). The $\mathrm{I}^{2}$ statistic yields results ranging between 0 and $100 \%(0-25 \%$, no heterogeneity; $25-50 \%$, moderate heterogeneity; $50-75 \%$, large heterogeneity; and $75-100 \%$, extreme heterogeneity). If heterogeneity was present, the random effects model was used, otherwise, the fixed effects model was used. A sensitivity analysis was conducted by switching the effects models. If possible, potential publication bias was assessed by a visual inspection of the funnel plots.

\section{Results}

Identification of eligible studies. Of the initial 132 references, five case-control studies $(15,19-22)$ were identified, including eight polymorphisms. A flow chart showing the study selection process is presented in Fig. 1.

Characteristics of studies. The detailed characteristics of the included studies are summarized in Tables I and II. All studies were published in English and the sample sizes ranged between

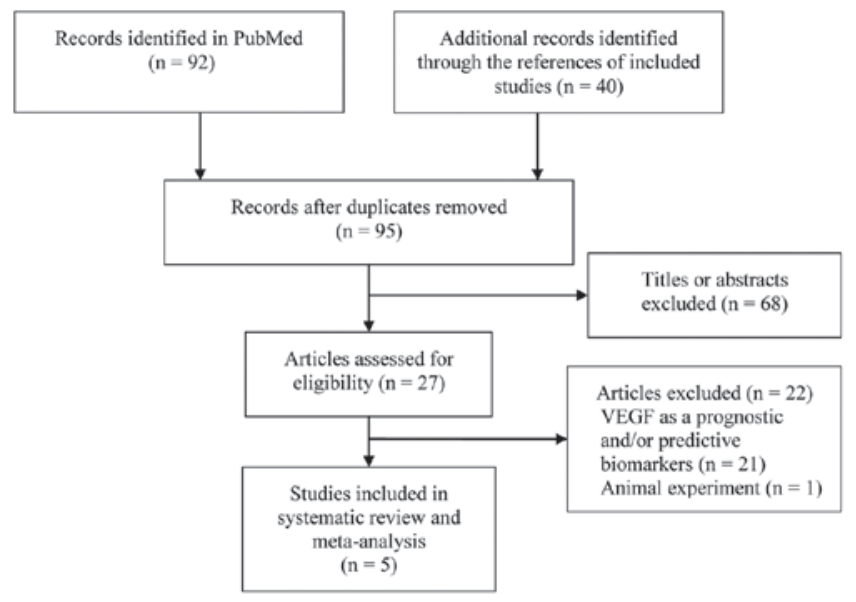

Figure 1. Flow diagram of the study selection process.

51 and 343 participants. The controls were all healthy individuals and were matched for age and gender. The genotypes of two studies $(19,20)$ were analyzed using PCR (polymerase chain reaction), two $(15,21)$ were analyzed by PCR-RFLP (restriction fragment length polymorphism) and one (22) by a TaqMan assay. The genotype distributions in the controls of all the studies were in accordance with the HWE.

Abe et al (15) studied three polymorphisms, 936C/T (rs3025039), 1612G/A (rs10434) and 702C/T. The study by Ricketts et al (19) was concerned with one polymorphism, -1154G/A (rs1570360). Bruyère et al (20) investigated five polymorphisms, 936C/T (rs3025039), -1154G/A (rs1570360), -2549I/D, -460T/C (rs833061) and 405G/C (rs2010963). Ajaz et al (21) surveyed two polymorphisms, -2578C/A (rs699947) and 936C/T (rs3025039). Sáenz-López et al (22) inquired about three polymorphisms, 936C/T (rs3025039), -460T/C (rs833061) and -2578C/A (rs699947).

936C/T polymorphism and $R C C$. A total of four studies $(15,20-22)$ investigated the $936 \mathrm{C} / \mathrm{T}$ polymorphism in RCC. Of these studies, three $(15,20,22)$ provided enough data to be combined. Figs. 2 and 3 show the results of the meta-analysis based on the fixed effects and random effects models, respectively. The results indicate that the VEGF gene 936C/T polymorphism was not associated with the risk of RCC.

Ajaz et al (21) did not report the number of each genotype distribution of the VEGF 936C/T polymorphism. They reported that the $936 \mathrm{C} / \mathrm{T}$ polymorphism lacked an association with RCC (OR, 1.5; 95\% CI, 0.7-3.3; $\mathrm{P}=0.36)$.

1612G/A polymorphism and RCC. Only Abe et al (15) investigated the VEGF gene 1612G/A polymorphism and RCC. The results showed no association between the $1612 \mathrm{G} / \mathrm{A}$ polymorphism and a risk of RCC [A vs. G (OR, 0.83; 95\% CI, 0.50-1.36; $\mathrm{P}=0.45)$; AA vs. GG (OR, 0.32; 95\% CI, 0.03-3.14; $\mathrm{P}=0.33)$; $\mathrm{AG}$ vs. GG (OR, 0.91; 95\% CI, 0.52-1.58; P=0.73); AA+AG vs. GG (OR, 0.86; 95\% CI, 0.50-1.48; P, 0.58); AA vs. GG+GA; OR, $0.33 ; 95 \% \mathrm{CI}, 0.03-3.20 ; \mathrm{P}=0.34)]$.

702C/T polymorphism and RCC. Abe et al (15) tested the VEGF gene $702 \mathrm{C} / \mathrm{T}$ polymorphism and $\mathrm{RCC}$. The results 


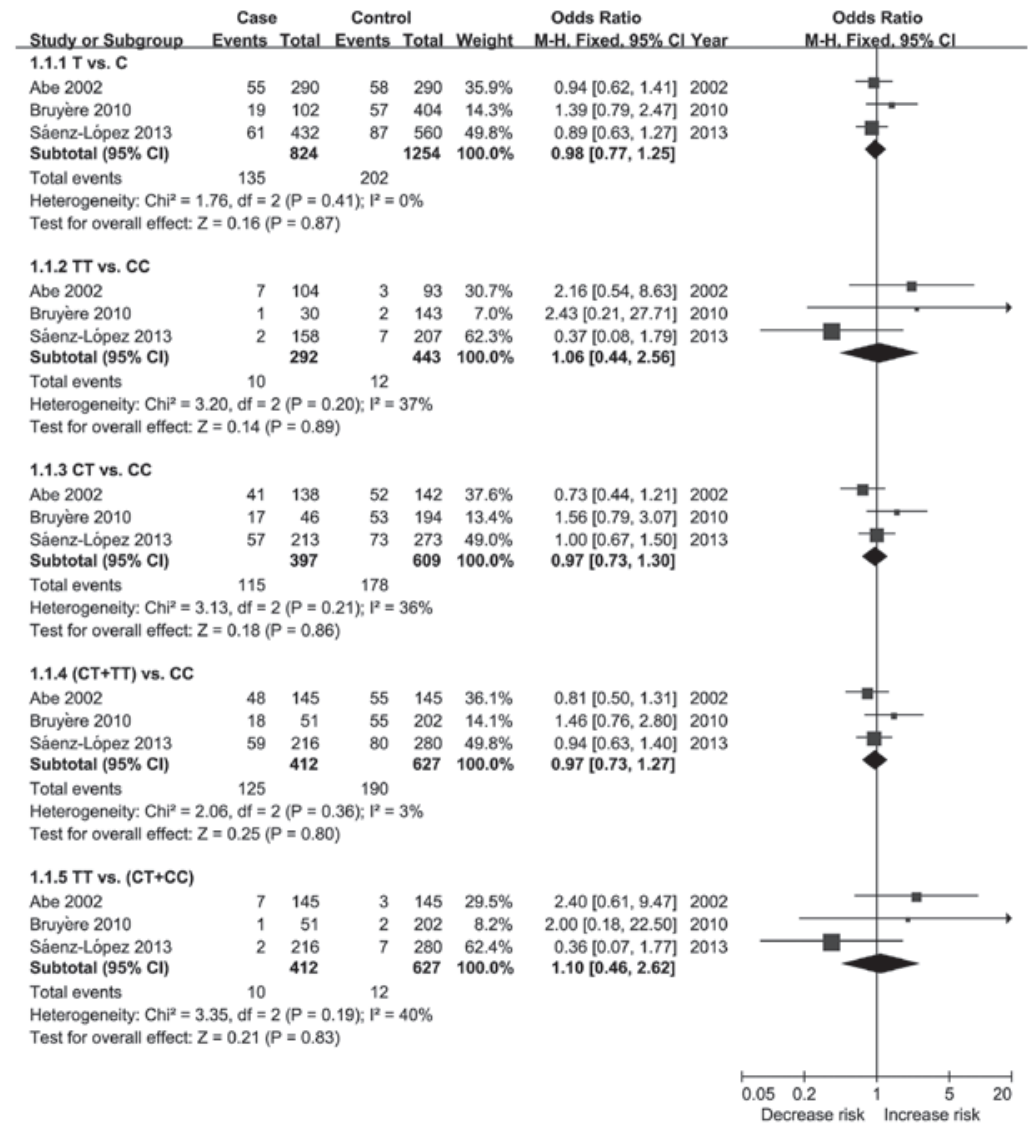

Figure 2. Forest plot of the association between the 936C/T polymorphism and RCC risk based on the fixed effects model. RCC, renal-cell carcinoma; CI, confidence interval.

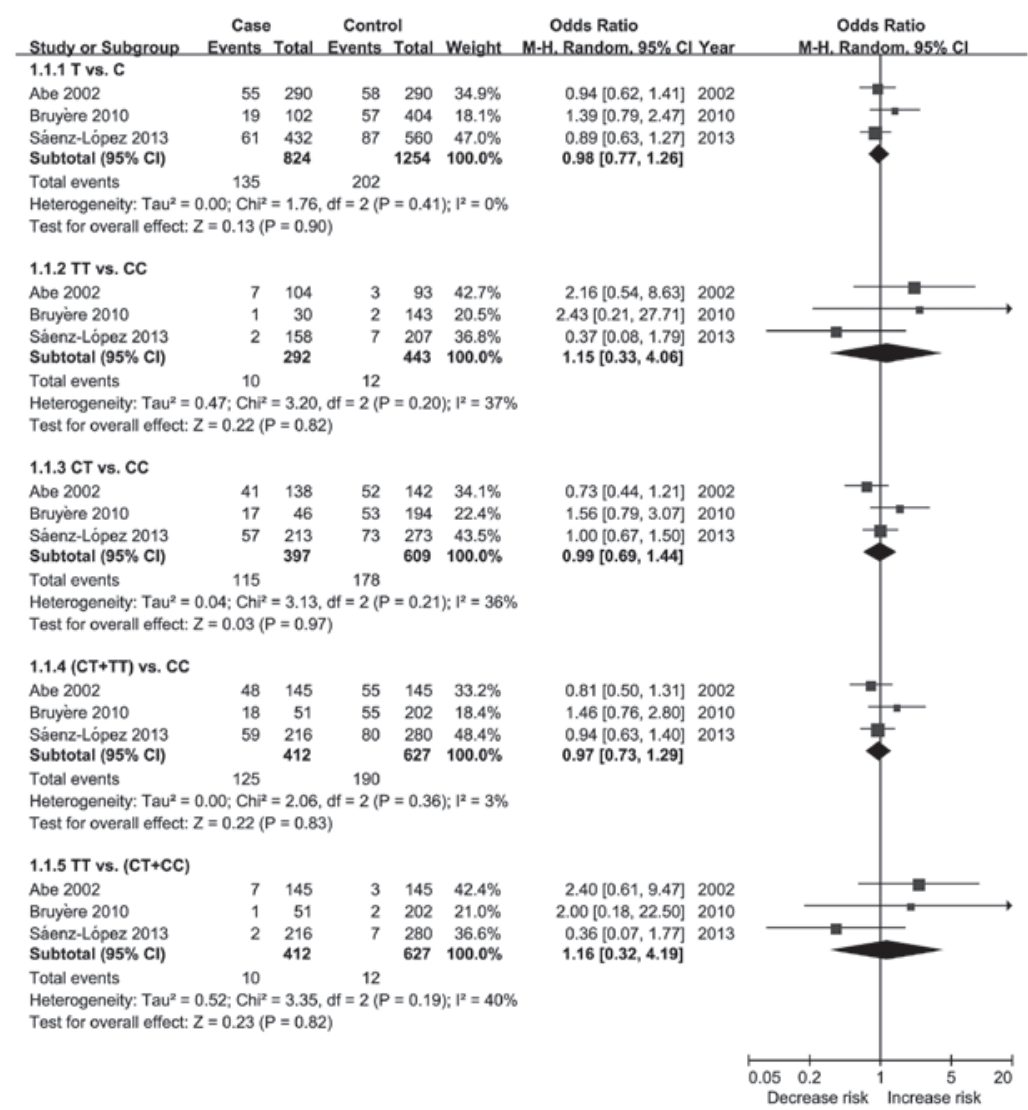

Figure 3. Forest plot of the association between the 936C/T polymorphism and RCC risk based on the random effects model. RCC, renal cell carcinoma, CI, confidence interval. 
Table I. Baseline characteristics of the included studies.

\begin{tabular}{|c|c|c|c|c|c|}
\hline \multirow[b]{2}{*}{ First author, year (ref) } & \multirow[b]{2}{*}{ Ethnicity } & \multicolumn{2}{|c|}{ Sample size, $\mathrm{n}$} & \multirow[b]{2}{*}{ Gene polymorphism } & \multirow[b]{2}{*}{ Genotyping method } \\
\hline & & Case & Control & & \\
\hline Abe et al, 2002 (15) & Asian & 145 & 145 & $\begin{array}{l}936 \mathrm{C} / \mathrm{T}(\mathrm{rs} 3025039), 1612 \mathrm{G} / \mathrm{A} \\
(\mathrm{rs} 10434), 702 \mathrm{C} / \mathrm{T}\end{array}$ & PCR-RFLP \\
\hline Ricketts et al, 2009 (19) & Caucasian & 343 & 321 & $-1154 \mathrm{G} / \mathrm{A}(\mathrm{rs} 1570360)$ & PCR \\
\hline Bruyère et al, 2010 (20) & Caucasian & 51 & 202 & $\begin{array}{l}\text { 936C/T (rs3025039), -1154G/A } \\
(\mathrm{rs} 1570360),-2549 \mathrm{I} / \mathrm{D},-460 \mathrm{~T} / \mathrm{C} \\
(\mathrm{rs} 833061), 405 \mathrm{G} / \mathrm{C}(\mathrm{rs} 2010963)\end{array}$ & PCR \\
\hline Ajaz et al, 2011 (21) & Asian & 143 & 106 & $\begin{array}{l}-2578 \mathrm{C} / \mathrm{A}(\mathrm{rs} 699947) 936 \mathrm{C} / \mathrm{T} \\
(\mathrm{rs} 3025039)\end{array}$ & PCR-RFLP \\
\hline Sáenz-López et al, 2013 (22) & Caucasian & 216 & 216 & $\begin{array}{l}936 \mathrm{C} / \mathrm{T}(\mathrm{rs} 3025039),-460 \mathrm{~T} / \mathrm{C} \\
(\mathrm{rs} 833061),-2578 \mathrm{C} / \mathrm{A}(\mathrm{rs} 699947)\end{array}$ & TaqMan \\
\hline
\end{tabular}

PCR-RFLP, polymerase chain reaction-restriction fragment length polymorphism.

Table II. Genotype distribution of all the included studies.

A, 936C/T (rs3025039)

\begin{tabular}{|c|c|c|c|c|c|c|c|c|c|}
\hline \multirow[b]{2}{*}{ Reference } & \multirow[b]{2}{*}{ Location } & \multicolumn{3}{|c|}{ Case } & \multirow[b]{2}{*}{ Source of control } & \multicolumn{3}{|c|}{ Control } & \multirow[b]{2}{*}{ P-value for $\mathrm{HWE}$} \\
\hline & & $\mathrm{CC}$ & $\mathrm{TT}$ & $\mathrm{CT}$ & & $\mathrm{CC}$ & $\mathrm{TT}$ & $\mathrm{CT}$ & \\
\hline Abe 2002 & 3'UTR & 97 & 41 & 7 & $\mathrm{HC}$ & 90 & 52 & 3 & 0.146 \\
\hline Bruyère 2010 & 3'UTR & 29 & 17 & 1 & $\mathrm{HC}$ & 141 & 53 & 2 & 0.124 \\
\hline Sáenz-López 2013 & 3'UTR & 156 & 57 & 2 & $\mathrm{HC}$ & 200 & 73 & 7 & 0.912 \\
\hline
\end{tabular}

B, 1612G/A (rs10434)

\begin{tabular}{|c|c|c|c|c|c|c|c|c|c|}
\hline \multirow[b]{2}{*}{ Reference } & \multirow[b]{2}{*}{ Location } & \multicolumn{3}{|c|}{ Case } & \multirow[b]{2}{*}{ Source of control } & \multicolumn{3}{|c|}{ Control } & \multirow[b]{2}{*}{ P-value for $\mathrm{HWE}$} \\
\hline & & GG & GA & AA & & GG & GA & $\mathrm{AA}$ & \\
\hline Abe 2002 & 3'UTR & 113 & 31 & 1 & $\mathrm{HC}$ & 109 & 33 & 3 & 0.788 \\
\hline
\end{tabular}

C, $702 \mathrm{C} / \mathrm{T}$

\begin{tabular}{|c|c|c|c|c|c|c|c|c|c|}
\hline \multirow[b]{2}{*}{ Reference } & \multirow[b]{2}{*}{ Location } & \multicolumn{3}{|c|}{ Case } & \multirow[b]{2}{*}{ Source of control } & \multicolumn{3}{|c|}{ Control } & \multirow[b]{2}{*}{ P-value for HWE } \\
\hline & & $\mathrm{CC}$ & $\mathrm{CT}$ & $\mathrm{TT}$ & & $\mathrm{CC}$ & $\mathrm{CT}$ & TT & \\
\hline Abe 2002 & 3'UTR & 145 & 0 & 0 & $\mathrm{HC}$ & 145 & 0 & 0 & l \\
\hline
\end{tabular}

D, - $1154 \mathrm{G} / \mathrm{A}(\mathrm{rs} 1570360)$

\begin{tabular}{|c|c|c|c|c|c|c|c|c|c|}
\hline \multirow[b]{2}{*}{ Reference } & \multirow[b]{2}{*}{ Location } & \multicolumn{3}{|c|}{ Case } & \multirow[b]{2}{*}{ Source of control } & \multicolumn{3}{|c|}{ Control } & \multirow[b]{2}{*}{ P-value for $\mathrm{HWE}$} \\
\hline & & GG & GA & AA & & GG & GA & AA & \\
\hline Ricketts 2009 & PR & 134 & 143 & 47 & $\mathrm{HC}$ & 146 & 130 & 38 & 0.281 \\
\hline Bruyère 2010 & PR & 27 & 17 & 5 & $\mathrm{HC}$ & 94 & 83 & 25 & 0.322 \\
\hline
\end{tabular}


Table II. Continued.

E, -2549I/D.

\begin{tabular}{|c|c|c|c|c|c|c|c|c|c|}
\hline \multirow[b]{2}{*}{ Reference } & \multirow[b]{2}{*}{ Location } & \multicolumn{3}{|c|}{ Case } & \multirow[b]{2}{*}{ Source of control } & \multicolumn{3}{|c|}{ Control } & \multirow[b]{2}{*}{$\mathrm{P}$-value for $\mathrm{HWE}$} \\
\hline & & II & ID & DD & & II & ID & $\mathrm{DD}$ & \\
\hline Bruyère 2010 & PR & 5 & 28 & 18 & $\mathrm{HC}$ & 45 & 108 & 49 & 0.322 \\
\hline
\end{tabular}

F, -460T/C (rs833061).

\begin{tabular}{|c|c|c|c|c|c|c|c|c|c|}
\hline \multirow[b]{2}{*}{ Reference } & \multirow[b]{2}{*}{ Location } & \multicolumn{3}{|c|}{ Case } & \multirow[b]{2}{*}{ Source of control } & \multicolumn{3}{|c|}{ Control } & \multirow[b]{2}{*}{ P-value for $\mathrm{HWE}$} \\
\hline & & TT & $\mathrm{TC}$ & $\mathrm{CC}$ & & $\mathrm{TT}$ & $\mathrm{TC}$ & $\mathrm{CC}$ & \\
\hline Bruyère 2010 & PR & 19 & 29 & 1 & $\mathrm{HC}$ & 47 & 109 & 46 & 0.260 \\
\hline Sáenz-López 2013 & PR & 56 & 111 & 49 & $\mathrm{HC}$ & 77 & 138 & 58 & 0.793 \\
\hline
\end{tabular}

G, $-405 \mathrm{G} / \mathrm{C}$ (rs2010963).

\begin{tabular}{|c|c|c|c|c|c|c|c|c|c|}
\hline \multirow[b]{2}{*}{ Reference } & \multirow[b]{2}{*}{ Location } & \multicolumn{3}{|c|}{ Case } & \multirow[b]{2}{*}{ Source of control } & \multicolumn{3}{|c|}{ Control } & \multirow[b]{2}{*}{ P-value for $\mathrm{HWE}$} \\
\hline & & GG & $\mathrm{GC}$ & $\mathrm{CC}$ & & GG & $\mathrm{GC}$ & $\mathrm{CC}$ & \\
\hline Bruyère 2010 & 5'UTR & 15 & 25 & 8 & $\mathrm{HC}$ & 86 & 92 & 20 & 0.522 \\
\hline Sáenz-López 2013 & 5'UTR & 101 & 93 & 20 & $\mathrm{HC}$ & 129 & 118 & 32 & 0.528 \\
\hline
\end{tabular}

H, -2578C/A (rs699947).

\begin{tabular}{|c|c|c|c|c|c|c|c|c|c|}
\hline \multirow[b]{2}{*}{ Reference } & \multirow[b]{2}{*}{ Location } & \multicolumn{3}{|c|}{ Case } & \multirow[b]{2}{*}{ Source of control } & \multicolumn{3}{|c|}{ Control } & \multirow[b]{2}{*}{$\mathrm{P}$-value for $\mathrm{HWE}$} \\
\hline & & $\mathrm{CC}$ & $\mathrm{CA}$ & AA & & $\mathrm{CC}$ & $\mathrm{CA}$ & AA & \\
\hline Ajaz 2011 & PR & 30 & 81 & 32 & $\mathrm{HC}$ & 44 & 41 & 21 & 0.053 \\
\hline Sáenz-López 2013 & PR & 54 & 114 & 48 & $\mathrm{HC}$ & 77 & 142 & 53 & 0.388 \\
\hline
\end{tabular}

UTR, untranslated region; PR, promoter reg.

showed that there was no polymorphism in $702 \mathrm{C} / \mathrm{T}$ in either the case or control groups (data shown in Table II).

-1154G/A polymorphism and RCC. A total of two studies $(19,20)$ investigated the $-1154 \mathrm{G} / \mathrm{A}$ polymorphism and RCC. Figs. 4 and 5 show the results of the meta-analysis based on the fixed effects and random effects models, respectively. The results indicate that the VEGF gene $-1154 \mathrm{G} / \mathrm{A}$ polymorphism was not associated with the risk of RCC.

-2549I/D polymorphism and RCC. Bruyère et al (20) analyzed the VEGF gene -2549I/D polymorphism and RCC. The results showed that the genotype at the -2549 polymorphism exhibited a non-significant trend for an increased risk of RCC. However, the D allele was associated with a significantly increased risk [D vs. I (OR, 1.62, 95\% CI, 1.04-2.53; $\mathrm{P}=0.03)$; DD vs. II (OR, 3.31; 95\% CI, 1.13-9.64, P=0.03); DI vs. II (OR,
2.33; 95\% CI, 0.85-6.43; P=0.10); DI+DD vs. II (OR, 2.64; 95\% CI, 0.99-7.03, $\mathrm{P}=0.05)$; DD vs. II+ID (OR, 1.70; $95 \% \mathrm{CI}$, 0.88-3.29; $\mathrm{P}=0.11)]$.

-460T/C polymorphism and RCC. A total of two studies $(20,22)$ investigated the $-460 \mathrm{~T} / \mathrm{C}$ polymorphism and RCC. Figs. 6 and 7 show the results of the meta-analysis based on the fixed effects and random effects models, respectively. The results indicated that the VEGF gene $-460 \mathrm{~T} / \mathrm{C}$ polymorphism was not associated with the risk of RCC.

$405 G / C$ polymorphism and $R C C$. A total of two studies $(20,22)$ investigated the $405 \mathrm{G} / \mathrm{C}$ polymorphism and RCC. Figs. 8 and 9 show the results of the meta-analysis based on the fixed effects and random effects models, respectively. The results indicate that the VEGF gene $405 \mathrm{G} / \mathrm{C}$ polymorphism exhibited a non-significant trend for an increased risk of RCC. 


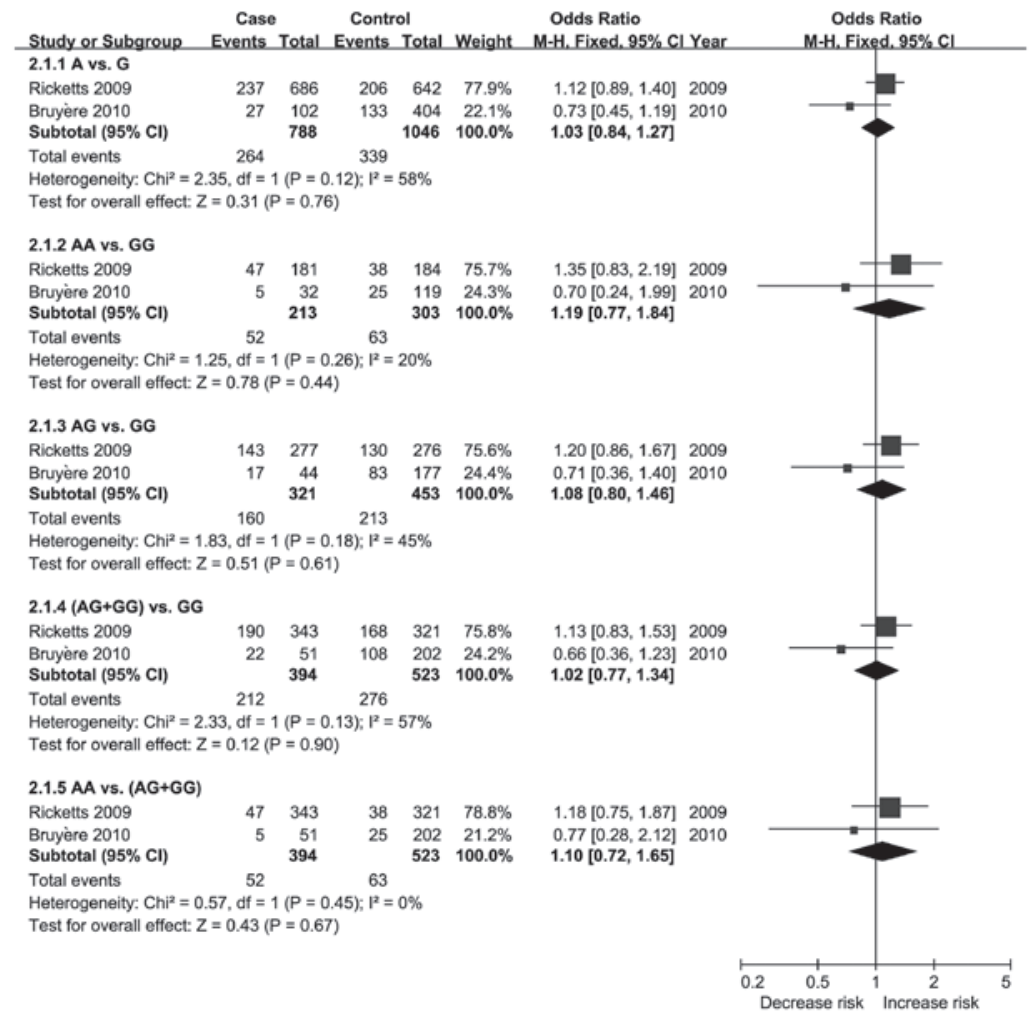

Figure 4. Forest plot of the association between the -1154G/A polymorphism and RCC risk based on the fixed effects model. RCC, renal-cell carcinoma; CI, confidence interval.

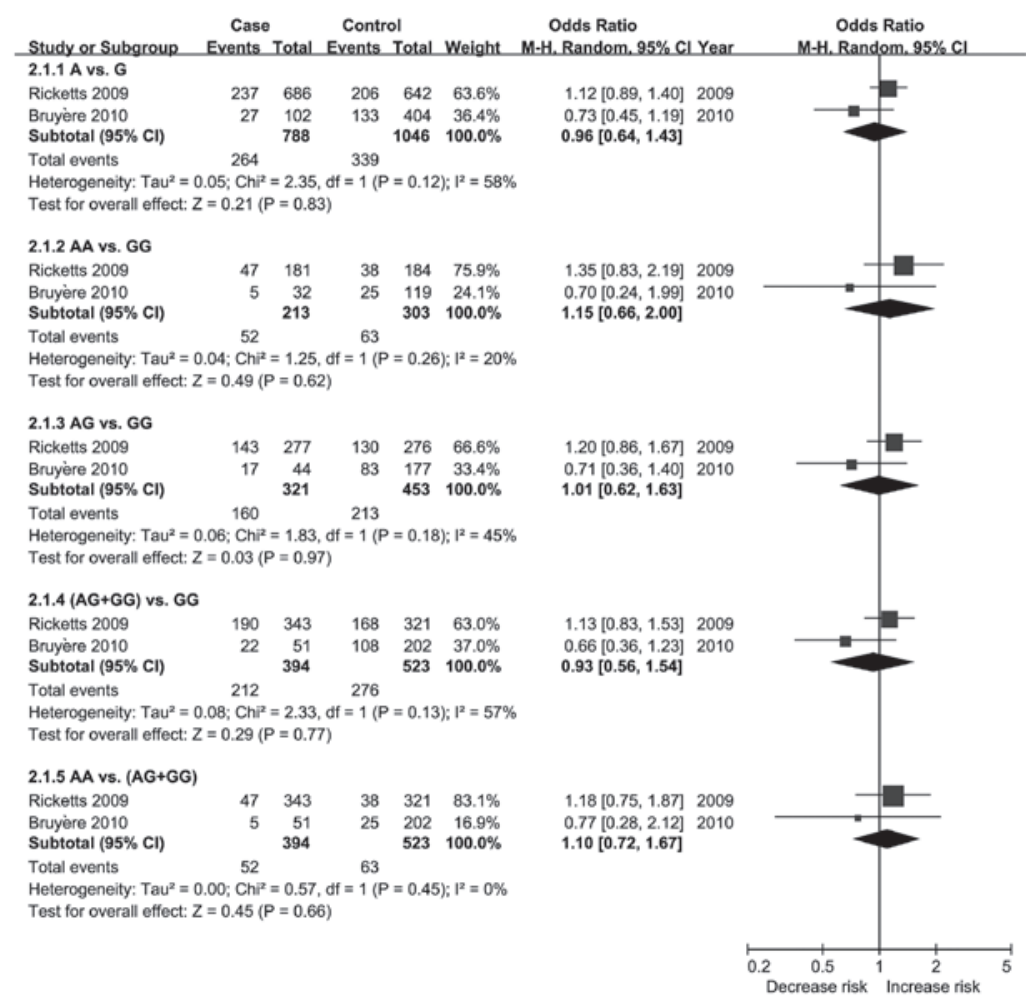

Figure 5. Forest plot of the association between the -1154G/A polymorphism and RCC risk based on the random effects model. RCC, renal-cell carcinoma; CI, confidence interval.

-2578C/A polymorphism and RCC.A total of two studies $(21,22)$ investigated the $-2578 \mathrm{C} / \mathrm{A}$ polymorphism and RCC. Based on the random effects model, the results show that the genotype at the $-2578 \mathrm{C} / \mathrm{A}$ polymorphism exhibited a non-significant trend for a significantly increased risk of RCC, but that the A allele was associated with an increased risk of RCC (Fig. 10). 


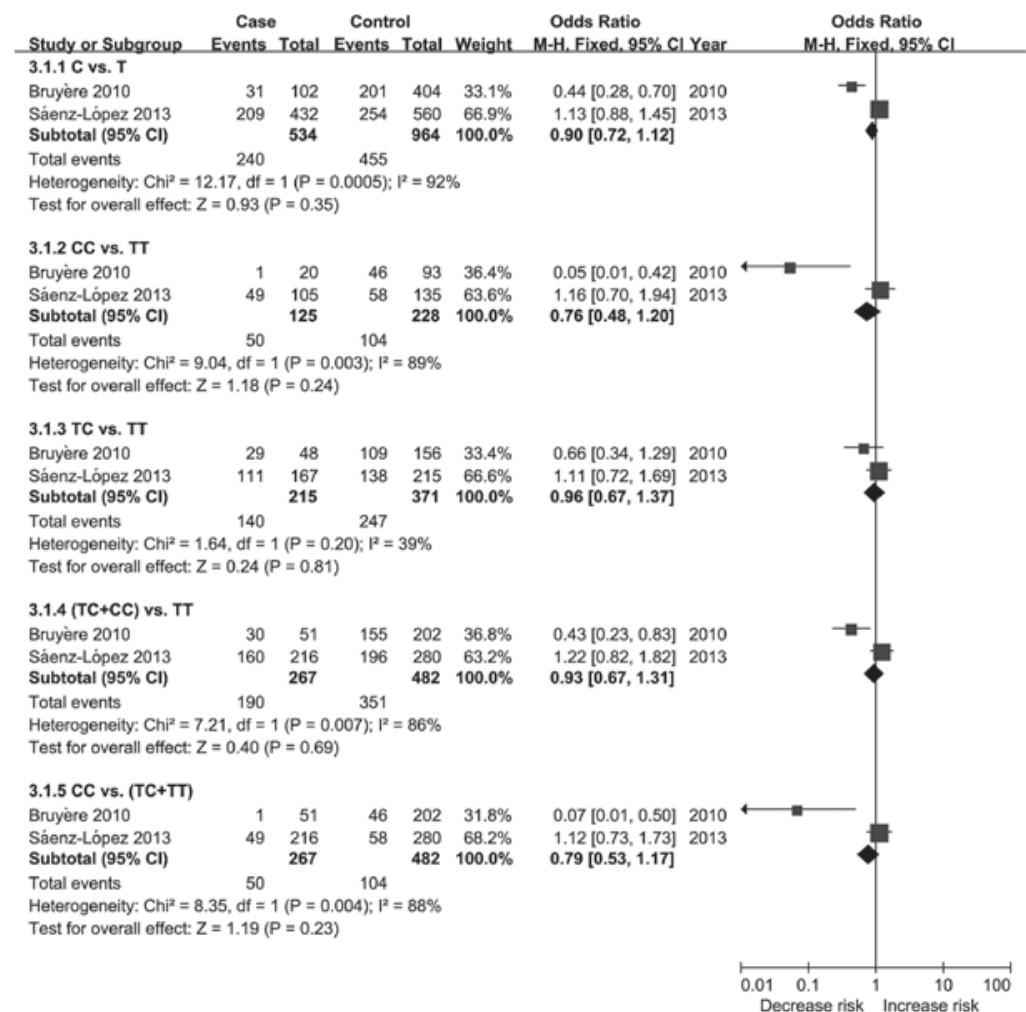

Figure 6. Forest plot of the association between the $-460 \mathrm{~T} / \mathrm{C}$ polymorphism and RCC risk based on the fixed effects model. RCC, renal-cell carcinoma; CI, confidence interval.

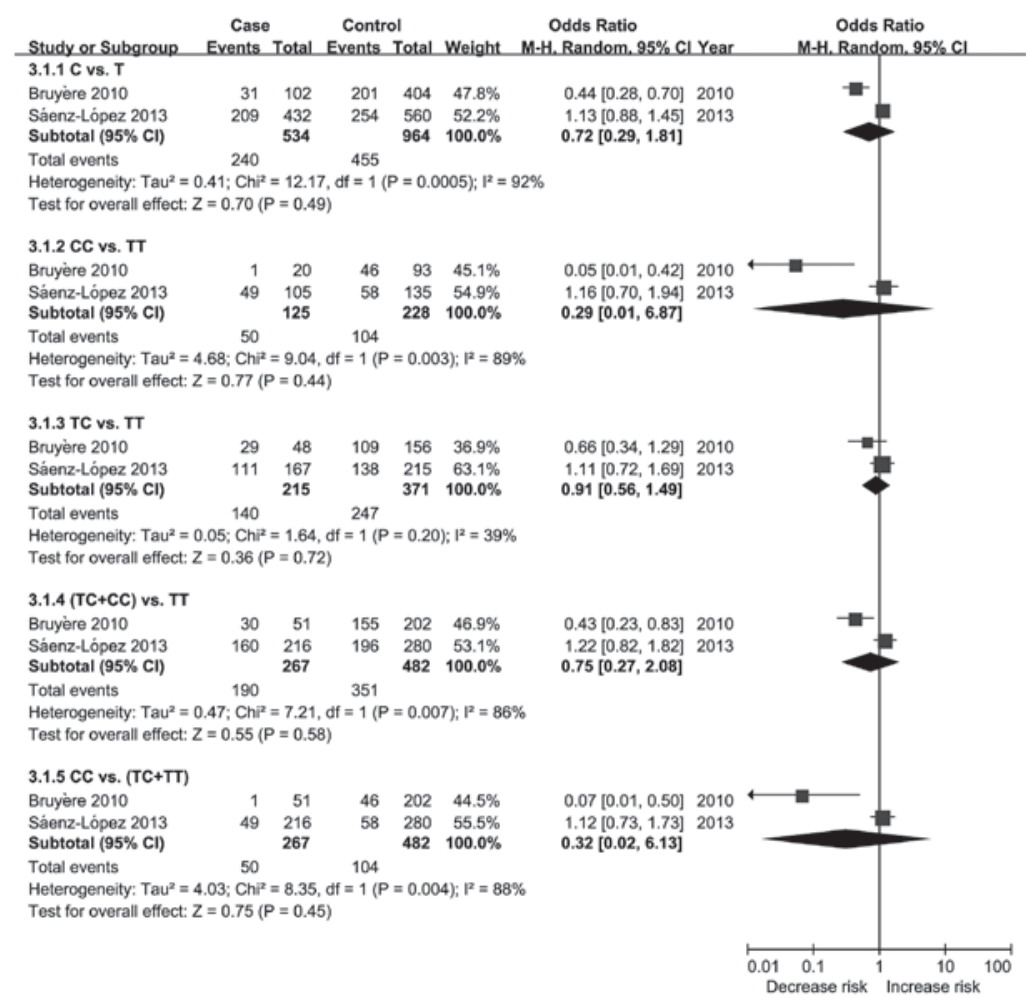

Figure 7. Forest plot of the association between the -460T/C polymorphism and RCC risk based on the random effects model. RCC, renal-cell carcinoma; CI, confidence interval.

However, when switched to the fixed effects model, the results show that the genotype at the $-2578 \mathrm{C} / \mathrm{A}$ polymorphism exhibited a significant trend for an increased risk of RCC (Fig. 11).

\section{Discussion}

The human VEGF gene is localized in chromosome 


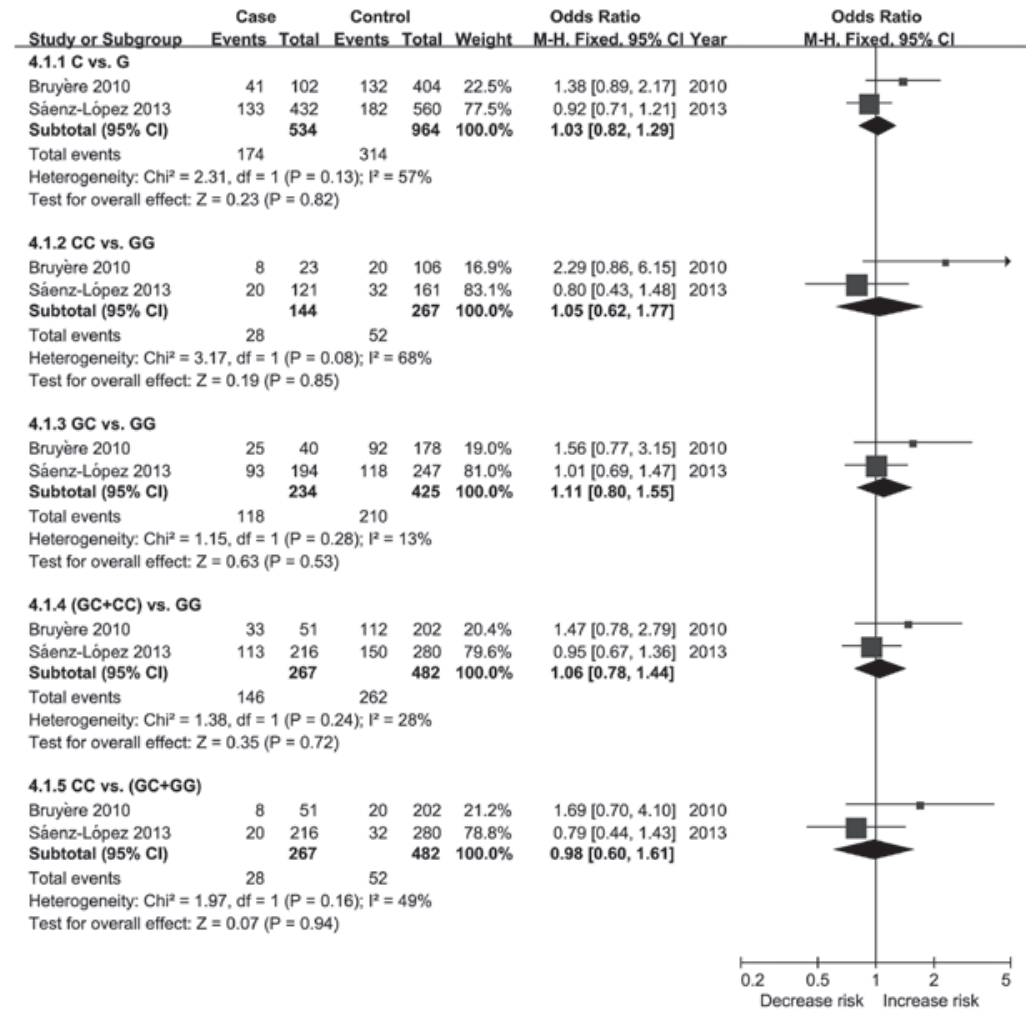

Figure 8. Forest plot of the association between the 405G/C polymorphism and RCC risk based on the fixed effects model. RCC, renal-cell carcinoma; CI, confidence interval.

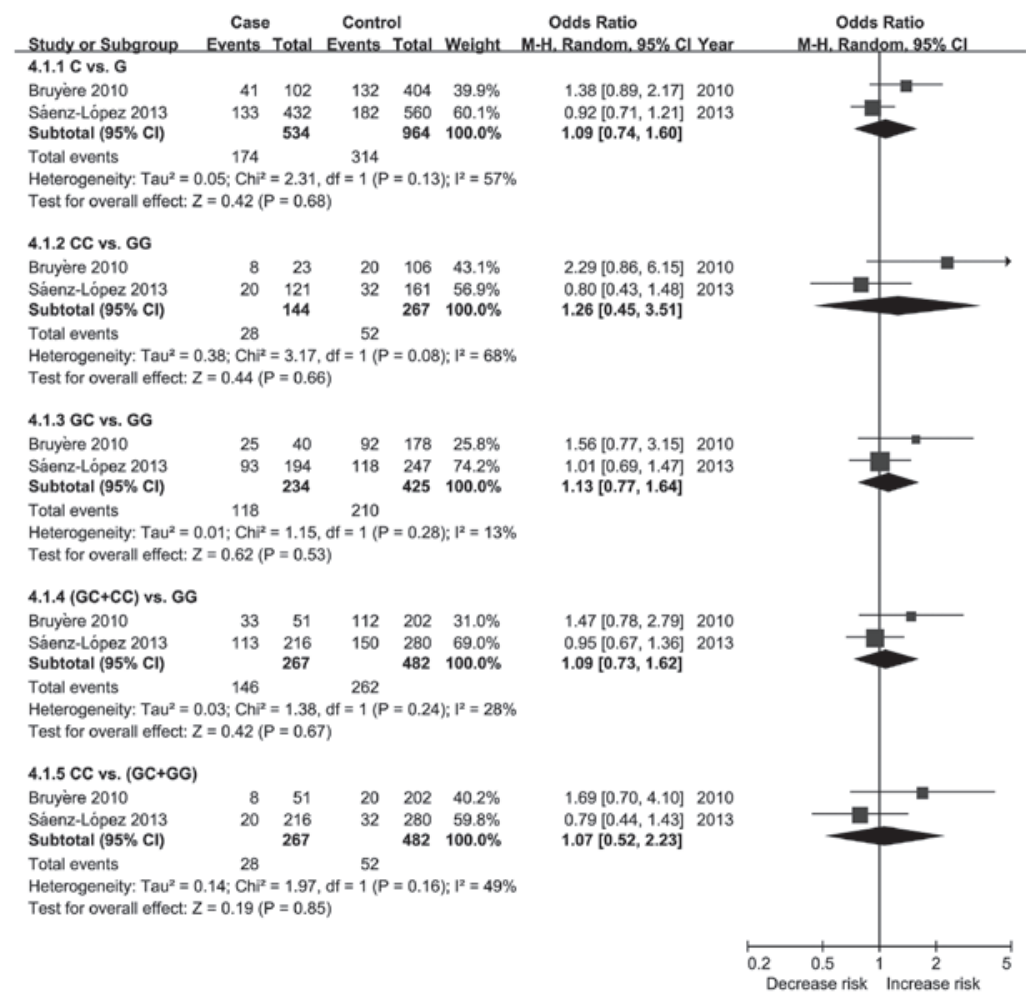

Figure 9. Forest plot of the association between the 405G/C polymorphism and RCC risk based on the random effects model. RCC, renal-cell carcinoma; CI, confidence interval.

$6 \mathrm{p} 21.3$ (23) and comprises a 14-kb coding region organized in eight exons, which are separated by seven introns (24). Experiments have shown that increased VEGF expression is associated with tumor growth and metastasis, and the inhibition of VEGF signaling has been shown to suppress tumor-induced angiogenesis and tumor growth (25). The 


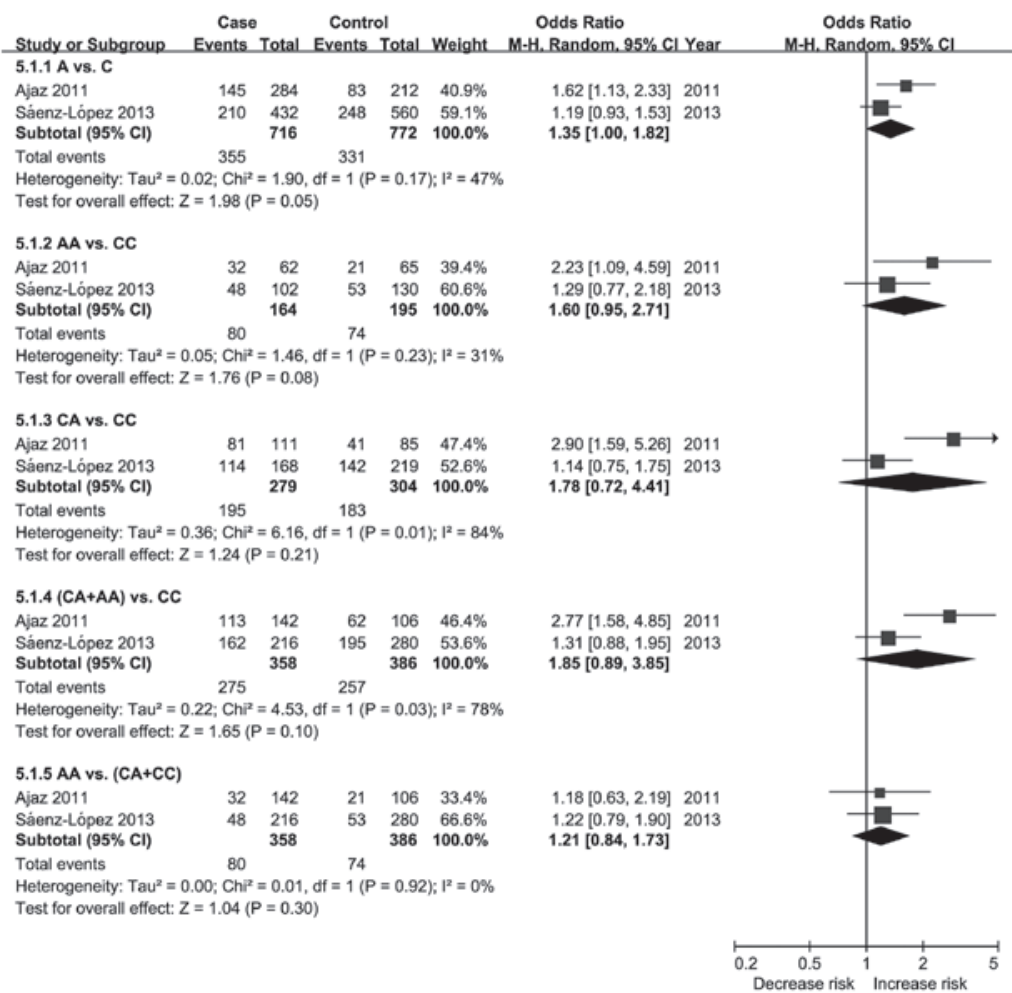

Figure 10. Forest plot of the association between the -2578C/A polymorphism and RCC risk based on the random effects model. RCC, renal-cell carcinoma; $\mathrm{CI}$, confidence interval.

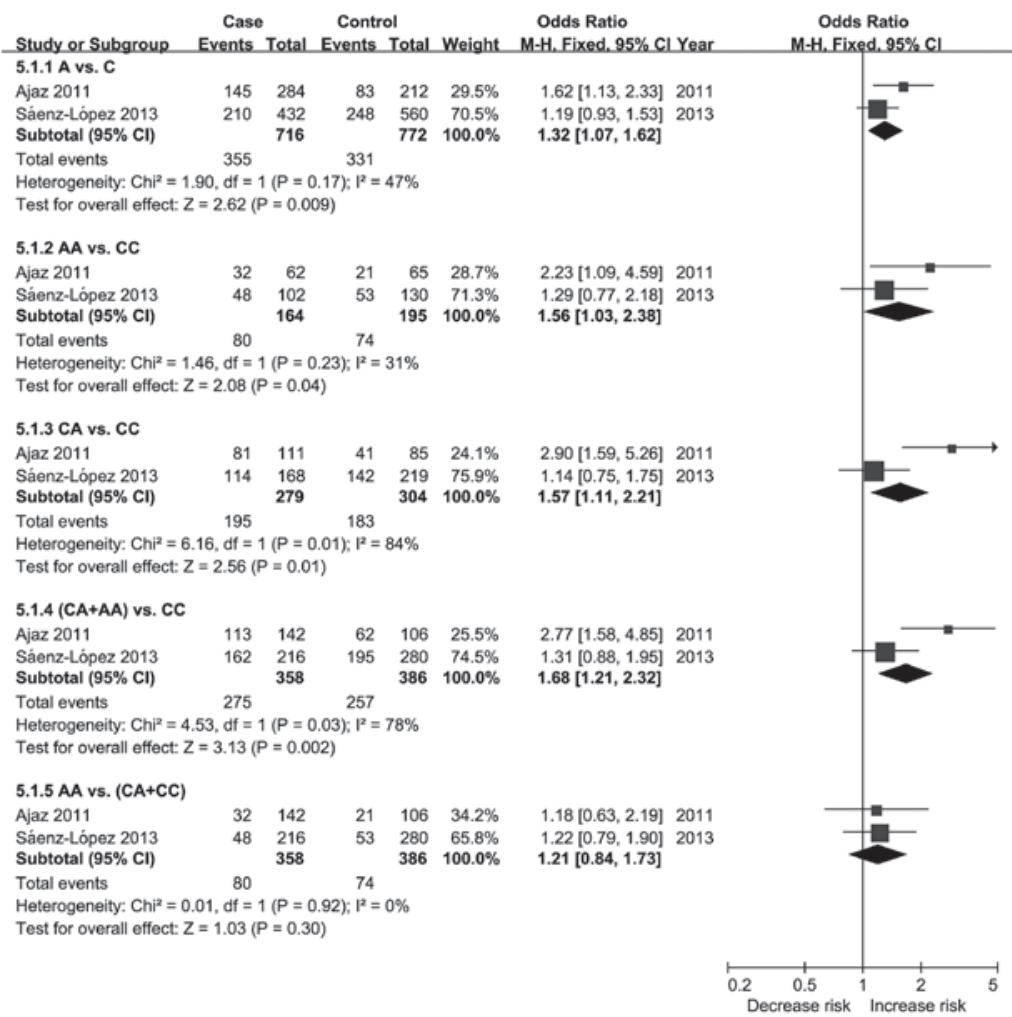

Figure 11. Forest plot of the association between the -2578C/A polymorphism and RCC risk based on the fixed effects model. RCC, renal-cell carcinoma; CI, confidence interval.

VEGF gene includes at least three polymorphisms that are relatively common and may affect VEGF expression. The insertion/deletion polymorphism (I/D) at the -2549 position of the promoter region and the $-634 \mathrm{G} / \mathrm{C}$ (rs2010963) polymorphism located in the 5'-UTR have been considered to be associated with increased VEGF expression $(26,27)$. 
The 936C/T (rs3025039) polymorphism located in the 3'-UTR is associated with substantially increased serum VEGF levels $(28,29)$. However, there are at least 30 single nucleotide polymorphisms in the VEGF gene that have been described (30). In addition, the VEGF family includes five VEGF ligands (VEGF-A, -B, -C and -D and platelet-derived growth factor), and three tyrosine kinase receptors (VEGFR-1, -2 and -3), which are involved in signaling pathways for angiogenesis and/or lymphangiogenesis (31). Therefore, an improved understanding of these markers is expected to reveal significant information with regard to the outcome and therapeutic efficacy in RCC. The present systematic review and meta-analysis was performed to investigate whether these three polymorphisms, and others, are associated with RCC.

This systematic review and meta-analysis addresses the association between eight VEGF gene polymorphisms and RCC susceptibility. Data from published studies were combined to evaluate the genetic associations between VEGF and the studied polymorphisms of the VEGF gene, namely, the $936 \mathrm{C} / \mathrm{T}, 1612 \mathrm{G} / \mathrm{A}, 702 \mathrm{C} / \mathrm{T},-1154 \mathrm{G} / \mathrm{A},-2549 \mathrm{I} / \mathrm{D},-460 \mathrm{~T} / \mathrm{C}$, $405 \mathrm{G} / \mathrm{C}$ and $-2578 \mathrm{C} / \mathrm{A}$ polymorphisms. No associations were identified between the 936C/T, 1612G/A, -1154G/A, -2549I/D, $-460 \mathrm{~T} / \mathrm{C}$ and 405G/C polymorphisms and RCC. However, the results did reveal a significant association between the $\mathrm{D}$ allele of the $-2549 \mathrm{I} / \mathrm{D}$ polymorphism and RCC. The $-2578 \mathrm{C} / \mathrm{A}$ polymorphism may be associated with RCC. For the $702 \mathrm{C} / \mathrm{T}$ polymorphism and $\mathrm{RCC}$, the results showed that there was no polymorphism in $702 \mathrm{C} / \mathrm{T}$ in either the case group or the control group. The results indicate that the $-2578 \mathrm{C} / \mathrm{A}$ polymorphism may be a risk factor for RCC susceptibility.

The present systematic review and meta-analysis has the following strengths. Firstly, the study is methodologically rigorous. The $\mathrm{Q}$ and $\mathrm{I}^{2}$ statistics were checked; the $\mathrm{I}^{2}$ statistic is more stable and is not affected as much by sample size (18). In the pooled analyses, fixed and random effects models were used to ensure the robustness of the estimates. Secondly, analysis comparisons of all five genetic models were performed, which provided enough information to detect the association. Finally, the literature search was extensive, locating all studies that had been published with regard to VEGF gene polymorphisms and RCC. Eight polymorphisms were identified, which is essential for the integrity of a comprehensive understanding of the correlation between VEGF gene polymorphisms and RCC.

This systematic review and meta-analysis has certain implications. Firstly, there was no polymorphism in $702 \mathrm{C} / \mathrm{T}$ in either the RCC group or the control group. Therefore, further studies have not been required to investigate this polymorphism and RCC. In fact, since the study by Abe et al (15) in 2002, no subsequent studies have investigated the VEGF gene $702 \mathrm{C} / \mathrm{T}$ polymorphism and RCC. Secondly, the $-2578 \mathrm{C} / \mathrm{A}$ polymorphism was associated with $\mathrm{RCC}$ risk in the fixed effects model, but heterogeneity was present and the credibility of the result was undermined. However, one of the included studies revealed an increased trend in the RCC risk and another indicated a statistically significant increased trend. Since the number and sample sizes of the two included studies were small, further studies that focus on this polymorphism are required. Thirdly, the result from the VEGF gene -2549I/D polymorphism exhibited a non-significant trend for an increased RCC risk in the DD vs. II, DI vs. II, DI+DD vs. II and DD vs. II+ID genetic models; however, the $\mathrm{D}$ allele was significantly associated with an increased $\mathrm{RCC}$ risk (OR, 1.62; 95\% CI, 1.04-2.53; $\mathrm{P}=0.03$ ). Only one study (20) detected the -2549I/D polymorphism and only two genetic models (D vs. I and DD vs. II) showed a significant difference. Further studies with regard to this polymorphism and RCC are required. Fourthly, there was no association between the 936C/T, 1612G/A, -1154G/A, -2549I/D, -460T/C and $405 \mathrm{G} / \mathrm{C}$ polymorphisms and the risk of $\mathrm{RCC}$, based on the fixed effects or random effects models. The meta-analysis included only three studies and further analyses are required to investigate these polymorphisms. Finally, in gene-targeted therapy (32), an assessment of the effectiveness of VEGF antibodies, including bevacizumab (33) and new VEGF inhibitor drugs for RCC are required.

However, the present results should be interpreted with caution due to the limitations apparent in this systematic review and meta-analysis. Firstly, only published studies were included in the study, therefore, publication bias may have occurred. Secondly, the number of studies and the sample sizes of each polymorphism were small, therefore, the statistical power is affected. Thirdly, the subjects in the present meta-analysis may be regarded as heterogeneous, as indicated by the heterogeneity test that made the reliable estimates should be discounted. Fourthly, this study is based on unadjusted estimates, while a more precise analysis may be performed if individual data were available. Finally, gene-gene and gene-environment interactions were not investigated due to a lack of such information in the included studies.

In conclusion, this systematic review and meta-analysis suggests that the VEGF 936C/T, 1612G/A, -1154G/A, -2549I/D, $-460 \mathrm{~T} / \mathrm{C}$ and $405 \mathrm{G} / \mathrm{C}$ gene polymorphisms are not associated with the risk of $\mathrm{RCC}$. There is no $702 \mathrm{C} / \mathrm{T}$ polymorphism in RCC and the $-2578 \mathrm{C} / \mathrm{A}$ gene polymorphism may be associated with an increased risk of RCC. Due to the limitations of the present study, further high quality case-control studies are warranted to confirm these findings.

\section{Acknowledgements}

The authors would like to thank Dr Xian-Tao Zeng (Department of Stomatology, Taihe Hospital, Hubei University of Medicine) for the invaluable discussions about the study design and statistical analyses.

\section{References}

1. Rini BI, Campbell SC and Escudier B: Renal cell carcinoma. Lancet 373: 1119-1132, 2009.

2. Gupta K, Miller JD, Li JZ, Russell MW and Charbonneau C: Epidemiologic and socioeconomic burden of metastatic renal cell carcinoma (mRCC): a literature review. Cancer Treat Rev 34: 193-205, 2008.

3. Hunt JD, van der Hel OL, McMillan GP, Boffetta P and Brennan P: Renal cell carcinoma in relation to cigarette smoking: meta-analysis of 24 studies. Int J Cancer 114: 101-108, 2005.

4. Bellocco R, Pasquali E, Rota M, et al: Alcohol drinking and risk of renal cell carcinoma: results of a meta-analysis. Ann Oncol 23: 2235-2244, 2012.

5. Bjørge T, Tretli S and Engeland A: Relation of height and body mass index to renal cell carcinoma in two million Norwegian men and women. Am J Epidemiol 160: 1168-1176, 2004. 
6. Bergström A, Hsieh CC, Lindblad P, Lu CM, Cook NR and Wolk A: Obesity and renal cell cancer - a quantitative review. Br J Cancer 85: 984-990, 2001.

7. McLaughlin JK, Chow WH, Mandel JS, et al: International renal-cell cancer study. VIII. Role of diuretics, other anti-hypertensive medications and hypertension. Int J Cancer 63: 216-221, 1995.

8. Ferrara N: Vascular endothelial growth factor. Trends Cardiovasc Med 3: 244-250, 1993.

9. Ferrara N and Davis-Smyth T: The biology of vascular endothelial growth factor. Endocr Rev 18: 4-25, 1997.

10. Zhou LP, Luan H, Dong XH, Jin GJ, Man DL and Shang H: Vascular endothelial growth factor $+936 \mathrm{C} / \mathrm{T}$ polymorphism and gastric cancer risk: A meta-analysis. Exp Ther Med 2: 931-936, 2011.

11. Kleinrouweler CE, Wiegerinck MM, Ris-Stalpers C, et al; EBM CONNECT Collaboration: Accuracy of circulating placental growth factor, vascular endothelial growth factor, soluble fms-like tyrosine kinase 1 and soluble endoglin in the prediction of pre-eclampsia: a systematic review and meta-analysis. BJOG 119: 778-787, 2012.

12. Toulis KA, Goulis DG, Mintziori G, et al: Meta-analysis of cardiovascular disease risk markers in women with polycystic ovary syndrome. Hum Reprod Update 17: 741-760, 2011.

13. Lambrechts D, Poesen K, Fernández-Santiago R, et al: Meta-analysis of vascular endothelial growth factor variations in amyotrophic lateral sclerosis: increased susceptibility in male carriers of the -2578AA genotype. J Med Genet 46: 840-846, 2009.

14. Banumathy G and Cairns P: Signaling pathways in renal cell carcinoma. Cancer Biol Ther 10: 658-664, 2010.

15. Abe A, Sato K, Habuchi T, et al: Single nucleotide polymorphisms in the 3' untranslated region of vascular endothelial growth factor gene in Japanese population with or without renal cell carcinoma. Tohoku J Exp Med 198: 181-190, 2002.

16. Moher D, Liberati A, Tetzlaff J and Altman DG; PRISMA Group: Preferred reporting items for systematic reviews and meta-analyses: the PRISMA statement. BMJ 339: b2535, 2009.

17. Higgins JP and Thompson SG: Quantifying heterogeneity in a meta-analysis. Stat Med 21: 1539-1558, 2002.

18. Higgins JP, Thompson SG, Deeks JJ and Altman DG: Measuring inconsistency in meta-analyses. BMJ 327: 557-560, 2003.

19. Ricketts C, Zeegers MP, Lubinski J and Maher ER: Analysis of germline variants in CDH1, IGFBP3, MMP1, MMP3, STK15 and VEGF in familial and sporadic renal cell carcinoma. PLoS One 4: e6037, 2009.

20. Bruyère F, Hovens CM, Marson MN, et al: VEGF polymorphisms are associated with an increasing risk of developing renal cell carcinoma. J Urol 184: 1273-1278, 2010.
21. Ajaz S, Khaliq S, Abid A, et al: Association of a single-nucleotide polymorphism in the promoter region of the VEGF gene with the risk of renal cell carcinoma. Genet Test Mol Biomarkers 15: 653-657, 2011.

22. Sáenz-Lopez P, Vazquez F, Cozar JM, Carretero R, Garrido F and Ruiz-Cabello F: VEGF polymorphisms are not associated with an increased risk of developing renal cell carcinoma in Spanish population. Hum Immunol 74: 98-103, 2013.

23. Lutty GA, McLeod DS, Merges C, Diggs A and Plouét J: Localization of vascular endothelial growth factor in human retina and choroid. Arch Ophthalmol 114: 971-977, 1996.

24. Vincenti V, Cassano C, Rocchi M and Persico MG: Assignment of the vascular endothelial growth factor gene to human chromosome 6p21.3. Circulation 93: 1493-1495, 1996.

25. Neufeld G, Cohen T, Gengrinovitch S and Poltorak Z: Vascular endothelial grow th factor (VEGF) and its receptors. FASEB J 13 9-22, 1999 .

26. Shahbazi M, Fryer AA, Pravica V, et al: Vascular endothelial growth factor gene polymorphisms are associated with acute renal allograft rejection. J Am Soc Nephrol 13: 260-264, 2002.

27. Lambrechts D, Storkebaum E, Morimoto M, et al: VEGF is a modifier of amyotrophic lateral sclerosis in mice and humans and protects motoneurons against ischemic death. Nat Genet 34: 383-394, 2003.

28. Renner W, Kotschan S, Hoffmann C, Obermayer-Pietsch B and Pilger E: A common $936 \mathrm{C} / \mathrm{T}$ mutation in the gene for vascular endothelial growth factor is associated with vascular endothelial growth factor plasma levels. J Vasc Res 37: 443-448, 2000.

29. Krippl P, Langsenlehner U, Renner W, et al: A common 936 $\mathrm{C} / \mathrm{T}$ gene polymorphism of vascular endothelial growth factor is associated with decreased breast cancer risk. Int J Cancer 106 : 468-471, 2003.

30. Watson CJ, Webb NJ, Bottomley MJ and Brenchley PE: Identification of polymorphisms within the vascular endothelial growth factor (VEGF) gene: correlation with variation in VEGF protein production. Cytokine 12: 1232-1235, 2000.

31. Lam JS, Leppert JT, Figlin RA and Belldegrun AS: Role of molecular markers in the diagnosis and therapy of renal cell carcinoma. Urology 66: 1-9, 2005.

32. Haviv YS and Curiel DT: Gene therapy for renal cancer. Contrib Nephrol 159: 135-150, 2008.

33. Hainsworth JD, Sosman JA, Spigel DR, Edwards DL, Baughman $\mathrm{C}$ and Greco A: Treatment of metastatic renal cell carcinoma with a combination of bevacizumab and erlotinib. J Clin Oncol 23: 7889-7896, 2005. 